\title{
Financial trend and status of commercial banks with reference to BSE \&NSE - A study
}

\author{
Mrs. Neelam Bharadwaj ${ }^{1}$, Dr.Puja Archana Sahu ${ }^{2}$ \\ ${ }^{1}$ Research Scholar, of Jain University \\ ${ }^{2}$ Professor, Administrative Management College, Bangalore
}

\begin{abstract}
Development of a country mostly depends upon the financial structure provided by the commercial banks. The responsibility of banks in the developing country like ours is crucial and significant. The financial position of the banks is more or less concurrent with their working capital and fixed assets. Where the coefficient correlation between the working capital and fixed assets are in a positive side the position is considered good. For our study we have taken into consideration one nationalized bank and two private banks, as after liberalization, the private commercial banks have evolved and are functioning at par with the government banks under the guidance of Reserve Bank of India. The researchers have chosen these three banks as they are listed in both NSE \& BSE Index. The purpose of this study is to find out, how far private banks are maintaining the ratio of their assets as well as their working capital as compared to the government banks. In support of this intention a relative study is conducted by choosing five years data from 2009 to 2013 of SBI, HDFC, \& ICICI banks.
\end{abstract}

Key words: Commercial Bank, working capital, fixed asset, liberalization policy, financial environment.

\section{Introduction}

The Indian banking sector has seen unprecedented growth along with remarkable improvement in its quality of assets and efficiency since economic liberalisation began in the early 1990s. The purpose of the study is to find out whether the private banks are matching their ratios with the government banks in their contribution towards economic development. Around the world, finance is a general filament which brings many sectors together and acts as catalyst for economic development. The role of banking sector in economic transformation is momentous as banks play vital role in providing the desired financial resources to the needy sectors. Thus, Banking is considered as the vertebrae of the economy. In emerging economies, banks are more than mere agents of financial intermediation and carry the additional responsibility of achieving the government's social agenda also. The survival and growth of the banks crucially depend on the size of the balance sheet as well as asset quality since the assets are the major source of income and life-line for the banks. In general GDP is considered as a significant variable affecting the banks performance (Siraj P Sudershan 2013). But banking sector stability is an important driver of future GDP growth (Balakrishnan, P. and Parameswaran, M. (2007). Banking is considered as number one service sector in India and its contribution for the tertiary sector in Indian economy is undoubtedly notable. Before liberalization policy there were only government banks extending its services to the private sector, government sector as well as fulfilling the need of individual requirement. But after liberalization so many private banks came up and are functioning at par with the government banks. In this study the researchers have tried to compare the various financial trends with regards to short term, longterm financial position as well as their profitability position. For this purpose we have used trend analysis as trend analysis is one of the instruments that help to analyze the company's monetary statement. In a trend analysis, the financial statements of the company are compared with each other for the several years after converting them in the percentage. Dr. Gupta (1997). The trend analysis also occupies an important place in the analysis\& interpretation of financial statements. Trend in general terms signifies a tendency.

\section{Scope and Objectives}

Scope is very enormous for this research topic. There are many nationalized as well as private commercial banks which are operating and providing their services for the growth and development of the country by providing finance to various sectors which in turn helps for their continual growth \& development. The main objectives of the study are -

- To find out and matching the ratio between the working capital and fixed assets for both category of banks,

- To find out the direction of the trends (i.e. upward or downward)and providing inferences to the management for future decision making 


\section{Methodology}

In order to accomplish the chalked out objectives of the study a detailed evaluation of sample banks are made with reference to BSE \& NSE sensex. The study has been made with the help of secondary data only. The secondary information is gathered from the official publications, financial records, published annual reports, text books, journals, and related website links. To justify our study we have taken the help of some statistical tools like Pearson's correlations, trend analysis, etc. In trend analysis, the financial statements of the company are compared with each other for several years after converting them into percentage.

\section{Analysis and interpretation}

Current financial position of sample banks are analysed by using the trend analysis method and shown in the following tables.

Table no.1 Short term current Financial Position of Banks:

\begin{tabular}{|c|c|c|c|c|c|c|}
\hline \multirow{2}{*}{ Year } & \multicolumn{2}{|c|}{ SBI } & \multicolumn{2}{c|}{ HDFC } & \multicolumn{2}{c|}{ ICICI } \\
\cline { 2 - 7 } & Working Capital & Trend\% & Working Capital & Trend\% & Working Capital & Trend\% \\
\hline 2009 & $\mathbf{3 1 4 3 9 . 5}$ & $\mathbf{1 0 0}$ & $\mathbf{1 1 4 2 . 8 3}$ & $\mathbf{1 0 0}$ & $\mathbf{1 0 3 8 3 . 7 5}$ & $\mathbf{1 0 0}$ \\
\hline 2010 & $\mathbf{5 0 9 5 9 . 9 1}$ & $\mathbf{1 6 2 . 0 8}$ & $\mathbf{1 5 2 8 . 1 6}$ & $\mathbf{1 3 3 . 7 1}$ & $\mathbf{4 2 5 8 7 . 4 4}$ & $\mathbf{4 1 0 . 1 3}$ \\
\hline 2011 & $\mathbf{6 1 4 0 3 . 6 1}$ & 195.30 & $\mathbf{1 5 2 7 7 . 0 6}$ & $\mathbf{1 3 3 6 . 7 7}$ & $\mathbf{3 4 4 5 1 . 2}$ & $\mathbf{3 3 1 . 7 7}$ \\
\hline 2012 & $\mathbf{6 9 3 6 1 . 1}$ & $\mathbf{2 2 0 . 6}$ & $\mathbf{5 2 2 7 . 4 9}$ & $\mathbf{4 5 7 . 4 1}$ & $\mathbf{3 8 1 6 7 . 7 2}$ & $\mathbf{3 6 7 . 5 7}$ \\
\hline 2013 & $\mathbf{6 7 2 5 7 . 1 2}$ & $\mathbf{2 1 3 . 9 2}$ & $\mathbf{1 1 4 3 0 . 4 1}$ & $\mathbf{1 0 0 0 . 1 8}$ & $\mathbf{3 8 3 7 0 . 9 9}$ & $\mathbf{3 6 9 . 5 2}$ \\
\hline
\end{tabular}

\section{Source: Money Control.com}

Table No. 2 Long term financial position of the Banks

\begin{tabular}{|c|c|c|c|c|c|c|c|c|c|c|c|c|}
\hline \multirow[b]{2}{*}{$\begin{array}{l}\text { Yea } \\
\text { r }\end{array}$} & \multicolumn{4}{|c|}{ SBI } & \multicolumn{4}{|c|}{ HDFC } & \multicolumn{4}{|c|}{ ICICI } \\
\hline & $\begin{array}{l}\text { Fixed } \\
\text { assets }\end{array}$ & $\begin{array}{l}\text { Trend } \\
\%\end{array}$ & $\begin{array}{l}\text { Total } \\
\text { Debt }\end{array}$ & $\begin{array}{l}\text { Trend } \\
\%\end{array}$ & $\begin{array}{l}\text { Fixed } \\
\text { assets }\end{array}$ & $\begin{array}{l}\text { Trend } \\
\%\end{array}$ & $\begin{array}{l}\text { Total } \\
\text { Debt }\end{array}$ & $\begin{array}{l}\text { Trend } \\
\%\end{array}$ & $\begin{array}{l}\text { Fixed } \\
\text { assets }\end{array}$ & $\begin{array}{l}\text { Trend } \\
\%\end{array}$ & $\begin{array}{l}\text { Total } \\
\text { Debt }\end{array}$ & $\begin{array}{l}\text { Trend } \\
\%\end{array}$ \\
\hline $\begin{array}{r}200 \\
9\end{array}$ & $\begin{array}{r}822295 . \\
01\end{array}$ & 100 & $\begin{array}{r}795786.8 \\
1\end{array}$ & 100 & $\begin{array}{r}159407 \\
.3 \\
\end{array}$ & 100 & $\begin{array}{r}145497 . \\
42\end{array}$ & 100 & $\begin{array}{r}325170 \\
.8\end{array}$ & 100 & $\begin{array}{r}285671 . \\
51\end{array}$ & 100 \\
\hline $\begin{array}{r}201 \\
0 \\
\end{array}$ & $\begin{array}{r}922117 . \\
13 \\
\end{array}$ & 112.13 & $\begin{array}{r}907127.8 \\
3 \\
\end{array}$ & 113.99 & $\begin{array}{r}186561 \\
.0 \\
\end{array}$ & 117.03 & $\begin{array}{r}180320 . \\
13 \\
\end{array}$ & 123.93 & $\begin{array}{r}305311 \\
.1 \\
\end{array}$ & 93.89 & $\begin{array}{r}296280 . \\
17 \\
\end{array}$ & 103.71 \\
\hline $\begin{array}{r}201 \\
1 \\
\end{array}$ & $\begin{array}{r}105708 \\
4.4 \\
\end{array}$ & 128.55 & $\begin{array}{r}1053501 . \\
77\end{array}$ & 132.38 & $\begin{array}{r}233082 \\
.7 \\
\end{array}$ & 146.2 & $\begin{array}{r}222980 . \\
47 \\
\end{array}$ & 153.25 & $\begin{array}{r}355796 \\
.1 \\
\end{array}$ & 109.41 & $\begin{array}{r}335156 . \\
39 \\
\end{array}$ & 117.32 \\
\hline $\begin{array}{r}201 \\
2 \\
\end{array}$ & $\begin{array}{r}118524 \\
3 \\
\end{array}$ & 144.13 & $\begin{array}{r}1170652 . \\
93 \\
\end{array}$ & 147.10 & $\begin{array}{r}295250 \\
.1 \\
\end{array}$ & 185.2 & $\begin{array}{r}270552 . \\
96 \\
\end{array}$ & 185.95 & $\begin{array}{r}417902 \\
.4 \\
\end{array}$ & 128.51 & $\begin{array}{r}395664 . \\
87 \\
\end{array}$ & 138.5 \\
\hline $\begin{array}{r}201 \\
3 \\
\end{array}$ & $\begin{array}{r}140354 \\
8.7 \\
\end{array}$ & 170.68 & $\begin{array}{r}1371922 . \\
28 \\
\end{array}$ & 172.39 & $\begin{array}{r}354037 \\
.3 \\
\end{array}$ & 222.09 & $\begin{array}{r}329253 . \\
58 \\
\end{array}$ & 226.29 & $\begin{array}{r}466290 \\
.1\end{array}$ & 143.39 & $\begin{array}{r}437955 . \\
12 \\
\end{array}$ & 153.25 \\
\hline
\end{tabular}

Source: Money Control.com

Table No. 3 Analysis of Profitability Position of the Bank:

\begin{tabular}{|c|c|c|c|c|c|c|}
\hline \multirow{2}{*}{ Year } & \multicolumn{2}{|c|}{ SBI } & \multicolumn{2}{c|}{ HDFC } & \multicolumn{2}{c|}{ ICICI } \\
\cline { 2 - 7 } & Reserves and surplus & Trend\% & Reserves and surplus & Trend\% & Reserves and surplus & Trend\% \\
\hline 2009 & 57312.82 & 100 & 14226.43 & 100 & 48419.73 & 100 \\
\hline 2010 & 65314.32 & 113.96 & 21064.75 & 148.06 & 50503.48 & 104.30 \\
\hline 2011 & 64351.04 & 112.28 & 24911.13 & 175.10 & 53938.82 & 111.39 \\
\hline 2012 & 83280.16 & 145.30 & 29455.04 & 207.04 & 59250.09 & 122.36 \\
\hline 2013 & 98199.65 & 171.33 & 35738.26 & 251.21 & 65547.84 & 135.3 \\
\hline
\end{tabular}

Source: Money Control.com

Table No. 4 Profit and loss Account analysis:

\begin{tabular}{|r|r|r|r|r|r|r|}
\hline \multirow{2}{*}{ Year } & \multicolumn{2}{|c|}{ SBI } & \multicolumn{2}{|c|}{ HDFC } & \multicolumn{2}{|c|}{ ICICI } \\
\cline { 2 - 7 } & Net Profit & Trend\% & Net Profit & Trend\% & Net Profit & Trend\% \\
\hline 2009 & 9121.23 & 100 & 2244.94 & 100 & 3758.13 & 100 \\
\hline 2010 & 9166.05 & 100.49 & 2948.70 & 131.34 & 4024.98 & 107.10 \\
\hline 2011 & 7370.35 & 80.80 & 3926.40 & 174.89 & 5151.38 & 137.07 \\
\hline 2012 & 11707.29 & 128.35 & 5167.09 & 230.16 & 6465.26 & 172.03 \\
\hline 2013 & 14104.98 & 154.63 & 6726.28 & 299.61 & 8325.47 & 221.55 \\
\hline
\end{tabular}

\section{Source: Money Control.com}

\section{Short term current financial position Of the Banks:}

From the above tables it has been revealed that Liquidity position of the SBI Bank is very sound, as working capital is showing upward trend from year 2009 to 2013. This depicts bank have enough current assets to pay off its current liabilities. In case of HDFC working capital has a shown upward trend from 2009 to 2011 , and in the year 2012 there is drastic down fall of working capital trend but in 2013 bank has shown upward trend of working capital. In ICICI Bank working capital trend is increasing from 2009 to 2010 but in 2011 trend 
has shown downward direction from $410 \%$ to $331 \%$ but again in 2011 and 2012 bank has shown upward direction of working capital.

\section{Long term financial position of the Banks:}

In SBI Fixed assets are showing upward trend from 2009 to 2013. On comparison fixed assets with long term debts, it reveals that every year from 2009 to 2012 fixed assets are more than long term debts. It can be assumed that that some portions of fixed assets are financed from working capital. During the year 2013 long term debts is more than a fixed asset. When the long term securities is more than fixed assets that indicates that bank have enough securities to finance fixed assets. Jain and Narang (2006) it is not desirable more long term funds should have been invested in fixed assets because a measure portion of long terms funds should be invested in fixed assets.

In HDFC and ICICI BANK, from the year 2009 to 2013 fixed assets are more than long term debts which show that part of fixed assets are financed from working capital.

\section{Profitability position of the Banks:}

Profitability position depends upon the reserves and surplus. All the Banks have enough reserves and surplus during the years 2009 to 2013 to meet any type of contingencies. All the banks during the period of study have shown upward trend in reserves and surplus, Jain, Narang, and Agarwal (2008) reserve is created out of profit and loss account and thus, is an appropriation of net profit for strengthen the financial position of the business.

\section{Findings of analysis of Income statements from the year 2009 to 2013}

HDFC Bank and ICICI Bank have shown upward direction of trend of net profits from 2009 to 2013. In SBI Bank from 2009 to 2010 there is increase in profit percentage, but in 2011 there is a decline in profits. The financial position of the banks positively reversed in the years 2012 and 2013.

Table No.5 Correlation between fixed asset $\&$ working capital

\begin{tabular}{|l|l|l|}
\hline Name of the banks & $\mathrm{r}$ & Significance \\
\hline SBI & 0.8522 & Positive high degree of correlation \\
\hline HDFC & 0.5631 & Good correlation \\
\hline ICICI & 0.3342 & Positive low degree of correlation \\
\hline
\end{tabular}

\section{Source: compilation of data}

The above table depicts that SBI is maintaining positive high degree of correlation among the working capital and fixed assets. With regard to HDFC the correlation is good but in case of ICICI, though it is positive but low degree of correlation. From the above it can be concluded that more or less all the sample banks are planning their financial status very meticulously.

\section{Conclusion}

After analysis of three leading banks named SBI,HDFC and ICICI it has been concluded that overall financial position of banks is very good. In case of SBI, Current short term financial position, profitability position and results of operations have shown increasing trend from 2009 to 2013. HDFC and ICICI have shown upward trend of working capital from year 2009 to 2010. In 2011 both these banks have downfall of working capital, but in 2012 and 2013 banks have again followed consistency of upward trend. Profitability position of ICICI and HDFC is very good. Only the problem lies with the long term financial position of the banks. But overall all the three banks are performing well.

\section{Limitation}

The study is limited to three banks only. In this study all the items of financial statements are not analysed, hence the findings cannot be considered as cent percent accurate. The further study in this matter is highly essential.

\section{Reference}

[1] Balakrishnan, P. and Parameswaran, M. (2007), "Understanding Economic Growth in India, Further Observations," Economic and Political Weekly, Nov 3, pp. 117-119.

[2] Dr.S.P.Gupta, Management Accounting, Kalyani Publication 1997 pg.171

[3] Jain SP, and Narang KL, Cost and Management Accounting, 2006 pg 109

[4] Jain, SP, Narang, KL, and Agarwal, S, Accounting for managers, Kalyani Publication, 2008, pp 119 Mony control.com

[5] Siraj P Sudershan 2013, Research Journal of Financing and Accounting vl 4 no.1 2013

[6] Services sector has been a major contributed to India's GDP and growth (Bhattacharya and Mitra 1990 BB hattacharya and Arup Mitra excess growth of tertiary sector in Indian economy, economic and political weekly vol. 25 no. 44 nov.3 1990 pp $2445-2450$ 
[7] Gorden and Gupta 2003 Banga 2005 Jain and Ninan 2010 have pointed out that india is not an outlier as the share of the services sector in GDP has increased with rise in per capita income. (Gordan,jim and poonam gupta 2010 the service sector as indias road to economic growth, ICRIER working paper no.249 april 10.

[8] In this respect, some economists (Ansari 1995) consider India as an outlier among South Asian countries and other emerging markets. Contending this view, Gordan and

[9] Gupta 2003, Banga 2005 and Jain and Ninan 2010 have pointed out that India is not an outlier as the share of services sector in GDP has increased with rise in per capita income.

[10] Ansari, M.I. (1995), "Explaining the Service Sector Growth: An Empirical Study of India, Pakistan, and Sri Lanka", Journal of Asian Economics, Vol. 6, No. 2, pp. 233-246.

[11] Gordon, Jim and Poonam Gupta (2003), "Understanding India's Services Revolution", Paper prepared for the IMF-NCAER Conference, “A Tale of Two Giants: India's and China's Experience with Reform”, November 14-16, 2003, New Delhi.

[12] Banga, Rashmi (2005), "Critical Issues in India's Service-led Growth”, ICRIER Working Paper No. 171, October, 2005.

[13] Jain, Sunil and T.N. Ninan (2010), "Servicing India's GDP Growth", in Acharya, Shankar and Rakesh Mohan (ed.), "India's Economy: Performance and Challenges - Essays in Honour of Montek Singh Ahluwalia”, Oxford University Press, pp. 328-365. 